\title{
DISCOVERY OF COLD-ACTIVE PROTEASE FROM PSYCHROPHILIC BACTERIA ISOLATED FROM ANTARCTIC REGION FOR BIO-PROSPECTING
}

\author{
MUHAMMAD ASYRAF ABD LATIP ${ }^{1}$, SITI AISYAH ALIAS ${ }^{2,6}$, JERZY SMYKLA ${ }^{3}$, FARIDAH YUSOF ${ }^{1}$, \\ MOHD AZRUL NAIM MOHAMAD ${ }^{4}$ and NOOR FAIZUL HADRY NORDIN ${ }^{* *}$ \\ ${ }^{1}$ Department of Biotechnology Engineering Department, Kulliyyah of Engineering, \\ International Islamic University Malaysia, Gombak, Malaysia \\ ${ }^{2}$ Institute of Ocean and Earth Sciences, University of Malaya, Kuala Lumpur, Malaysia \\ ${ }^{3}$ Institute of Nature Conservation, Polish Academy of Sciences, Kraków, Poland \\ ${ }^{4}$ Department of Biotechnology, Kulliyyah of Science, \\ International Islamic University Malaysia, Kuantan, Malaysia \\ International Institute for Halal Research and Training (INHART), \\ International Islamic University Malaysia, Gombak, Malaysia \\ ${ }^{6}$ National Antarctic Research Centre, University of Malaya, \\ 50603 Kuala Lumpur, Malaysia \\ *E-mail: faizul@iium.edu.my
}

Accepted 15 February 2020, Published online 30 June 2020

\begin{abstract}
The Antarctic region is a new frontier as natural sources for bio-prospecting purposes. Its extreme cold temperature may provide unique enzyme characteristics that have valuable potential for industrial and biotechnological applications. This study was designed to discover proteases that are activate and can work at very low temperatures. Soil samples from the Antarctic region were screened for protease activity on skim milk agar at $4{ }^{\circ} \mathrm{C}$. Bacteria that showed clear halo zone around the colonies were selected and identified through 16S rDNA sequencing. Out of 35 bacteria, 10 bacteria that showed rapid halo zone formation were selected and further analyzed by enzymatic assay. By using azocasein as a substrate, the reaction was measured using spectrophotometer at OD340 $\mathrm{nm}$. Based on the $16 \mathrm{~S}$ rDNA sequence, phylogenetic analysis showed that $88 \%$ of the bacteria producing protease were from Pseudomonas sp., 9\% from Arthrobacter sp. and 3\% from Paenibacillus sp. For enzymatic assay analysis, sample SC 8 showed the highest protease activity compared to other 10 samples. This preliminary study successfully demonstrated cold active protease producers that can be further investigated for bioprospecting. In future, purification and characterization of this enzyme is required in order to optimize the enzyme activity.
\end{abstract}

Key words: Cold-active protease, Antarctica, bio-prospecting, biotechnology

\section{INTRODUCTION}

Antarctica is a pristine place with very cold temperatures. Although it seems not to be livable, there is a diverse microorganism community that can thrive in these extreme conditions. Their survival at these very low-temperature conditions is very fascinating. Many researchers have studied their unique features on how they can work at such low temperatures (De Maayer et al., 2014; Elleuche et al., 2014). Among the unique features that psychrophiles possess, one is the production of

* To whom correspondence should be addressed. enzymes that are active in low temperatures. Recently, novel cold-active and alkaline pectate lyase has been characterized and extracted from Antarctica bacterium (Tang et al., 2019). Coldactive enzymes originated from these psychrophilic microbes have shown a lot of advantages either in industrial processing or biotechnological applications. With lower activation energy, it can economically save the energy and reduce the cost of production (Siddiqui \& Cavicchioli, 2006). Besides, compared to the chemical catalysts this biocatalyst is more environmental friendly (Barroca et al., 2017). As for food industries, it can maintain the taste and food structure while reducing the risk 
of spoilage or contamination. This experiment was carried out to identify Antarctic bacteria that can produce cold-active extracellular protease for bioprospecting.

\section{MATERIALS AND METHODS}

\section{Sample collection}

Soil samples utilized in this study were collected from the coastal environments of the Southern Victoria Land and Ross Island (Ross Sea region, continental Antarctic) in 2012 from the project of J. Smykla. The field survey and soil sampling strategy included a range of different terrestrial environments and was described in detail by Smykla et al. (2015). Briefly, the samples were collected from the upper soil layer $(0-10 \mathrm{~cm}$ deep) using a sterile scoop, and then placed into sterile polyethylene bags (Whirl-Pack $\left.{ }^{\circledR}\right)$. Within a few hours after collection, the samples were transported to the US Antarctic Station McMurdo and frozen by reducing the temperature over 48 hours period from 1 to $-20^{\circ} \mathrm{C}$. The samples were then shipped and stored in a frozen state for processing and analysis to the National Antarctica Research Center (NARC), University of Malaya.

\section{Screening on skim milk agar}

Proteolytic activity was screened on skim milk agar. A mass of $5 \mathrm{~g}$ Antarctic sediment was diluted with $10 \mathrm{~mL}$ of sterile distilled water. The sample was mixed by vortexing and centrifuged at $5000 \mathrm{X} \mathrm{g}$ for 10 minutes. The supernatant was used for ten-fold serial dilution. Then, $200 \mathrm{~mL}$ from the serial dilution were spread on the skim milk agar and incubated at $4{ }^{\circ} \mathrm{C}$. The colonies that showed halo zone (Figure 1) were selected and transferred into LB broth. Then, from the broth, the bacteria were stored at $-80^{\circ} \mathrm{C}$ with $25 \%$ glycerol.

\section{DNA-based bacterial identification}

DNA extraction was done by heat and boiled techniques. Each colony was cultured on LB agar overnight and transferred into $200 \mu \mathrm{L}$ of sterile distilled water. The bacterial suspension was boiled at $100^{\circ} \mathrm{C}$ for 15 minutes and centrifuged at $2000 \mathrm{X} \mathrm{g}$. The supernatant was used as DNA sample for PCR amplification. PCR amplification was performed according to the standard protocol of BIOTAQ ${ }^{\mathrm{TM}}$ DNA Polymerase using primer $27 \mathrm{~F}$ (5'-AGAGTTTGATCCTGGCTCAG-3') and 1492R (5'-GGTTACCTTGTTACGACTT-3') (Chen et al., 2015). Purified PCR products were sent for sequencing and analyzed by blasting in NCBI website.

\section{Enzymatic assays}

From the skim milk agar screening, ten bacteria strains were selected to proceed with enzymatic assay. The reaction mixture contained $250 \mu \mathrm{L}$ of bacteria culture with OD600 $0.1,250 \mu \mathrm{L}$ of $1 \%$ Azocasein and $250 \mu \mathrm{L}$ of $0.5 \mathrm{M}$ Tris. The mixture was incubated for 24 hours at $4{ }^{\circ} \mathrm{C}$ and $200 \mathrm{rpm}$. The reaction was stopped by adding $25 \%$ of trichloroacetic acid (TCA) and centrifuged at $11000 \mathrm{X} \mathrm{g}$ for 30 minutes at room temperature. The supernatant was transferred into a new cuvette and read at OD340 $\mathrm{nm}$ and $37^{\circ} \mathrm{C}$. Pseudomonas aeruginosa ATCC 27853 was used as positive control, because of its known proteolytic activity on skim milk agar (Brown \& Foster, 1970). The data was represented as enzyme unit mean \pm standard error mean (SEM). Statistical analysis was calculated a)

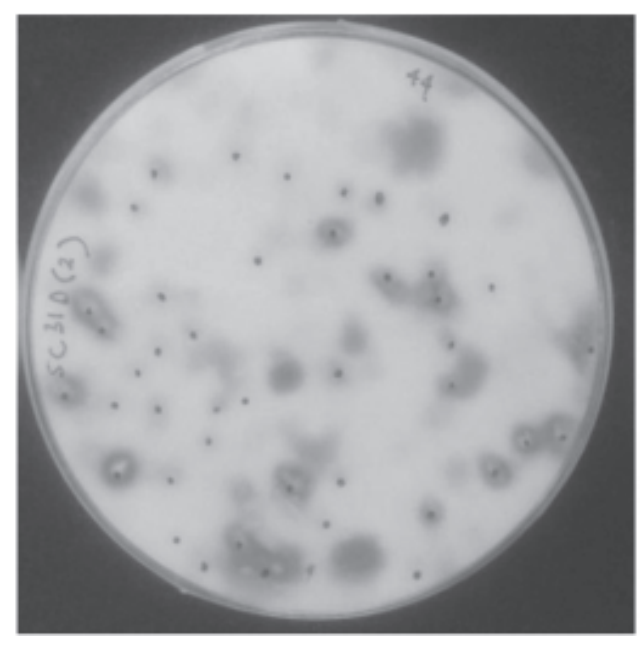

b)

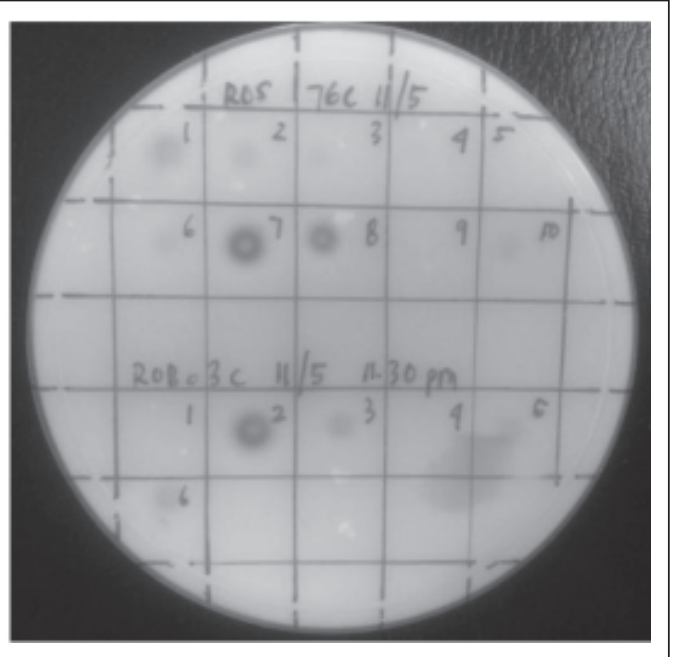

Fig. 1. a) Halo zone formation around the colonies indicated proteolytic activity. b) Each strain was re-screened to identify colony with clear halo zone formation after 24 hours. 
using one-way analysis of variance (ANOVA), SPSS 26.0. The results were considered significant, if the p-value was $<0.05$.

\section{RESULTS AND DISCUSSION}

Skim milk agar method was generally used to screen protease activity (Harer et al., 2018). Clear halo zone formation around the colony showed that the bacteria produced extracellular protease. These bacteria excreted the enzyme out of the membrane cell to digest casein around the colony. From this agar screening, 35 colonies showed positive proteolytic activity, thus were selected and patched onto new Luria-Bertani (LB) agar. Based on Table 1, phylogenetic analysis showed that 31 out of $35(88 \%)$ colonies were from Pseudomonas sp., and another three $(8 \%)$ and one $(3 \%)$ colonies were from Arthrobacter sp. and Paenibacillus sp. respectively. Pseudomonas sp. is a Gram-negative strain that belongs to the class Gammaproteobacteria. This species colonized various type of environments including soil, water and plant. Besides, it can adapt with their surrounding environment very well. It also has been reported to inhabit the extreme cold Antarctic region. Many strains of Pseudomonas have been isolated from this extreme cold region (Reddy et al., 2014). Pseudomonas antarctic was one of the strains that have been characterised and isolated from this polar region. Besides, proteolytic activity of this species has been reported by Martínez-Rosales and CastroSowinski (2011).

In relation to Arthrobacter sp., Arthrobacter antarcticus has been isolated from Southern Ocean sediment off the Antarctic (Pindi et al., 2010). This species has been reported to produce cold active protease (Kim et al., 2010). In this study, there were three strains of Arthrobacter sp. that have been

Table 1. Highest sequence similarity of isolated bacteria that showed proteolytic activity on skim milk agar based on BLAST sequence alignment

\begin{tabular}{|c|c|c|c|c|c|}
\hline Isolates & Possible organism & $\begin{array}{l}\text { Sequence } \\
\text { Length (bp) }\end{array}$ & $\begin{array}{l}\text { Max Score/ } \\
\text { Total Score }\end{array}$ & $\begin{array}{c}\text { Max. } \\
\text { Identity (\%) }\end{array}$ & $\begin{array}{c}\text { GenBank } \\
\text { accession number }\end{array}$ \\
\hline BB1 & Pseudomonas brassicacearum & 1051 & 1230 & 94 & NR_116299.1 \\
\hline BB8 & Pseudomonas gessardii & 723 & 1033 & 97 & NR_024928.1 \\
\hline BB16 & Pseudomonas silesiensis & 566 & 737 & 97 & NR_156815.1 \\
\hline CR25 & Paenibacillus xylanexedens & 618 & 863 & 98 & NR_044524.1 \\
\hline DI23 & Pseudomonas mandelii & 1199 & 2049 & 99 & NR_114216.1 \\
\hline DI25 & Pseudomonas mandelii & 1185 & 1661 & 95 & NR_114216.1 \\
\hline MP1 & Pseudomonas marginalis & 718 & 989 & 96 & NR_112072.1 \\
\hline MP2 & Pseudomonas mandelii & 1216 & 2122 & 98 & NR_114216.1 \\
\hline MP4 & Pseudomonas baetica & 1194 & 1724 & 95 & NR_116899.1 \\
\hline MP7 & Pseudomonas prosekil & 625 & 939 & 99 & NR_132724.1 \\
\hline MP8 & Pseudomonas corrugata & 1447 & 758 & 95 & NR_117826.1 \\
\hline MP9 & Pseudomonas canadensis & 595 & 758 & 98 & NR_156852.1 \\
\hline MP12 & Pseudomonas prosekil & 638 & 941 & 99 & NR_132724.1 \\
\hline MP13 & Pseudomonas migulae & 905 & 1181 & 93 & NR_114223.1 \\
\hline ROB1 & Pseudomonas helmanticensis & 1260 & 2189 & 98 & NR_126220.1 \\
\hline ROB6 & Pseudomonas arsenicoxydans & 1717 & 2303 & 97 & NR_117022.1 \\
\hline ROS1 & Pseudomonas azotoformans & 1476 & 2283 & 96 & NR_113600.1 \\
\hline ROS2 & Pseudomonas azotoformans & 803 & 1384 & 99 & NR_113600.1 \\
\hline ROS3 & Pseudomonas lactis & 1150 & 1557 & 95 & NR_156986.1 \\
\hline ROS4 & Pseudomonas marginalis & 1208 & 2106 & 98 & NR_117821.1 \\
\hline ROS5 & Pseudomonas marginalis & 1210 & 2021 & 99 & NR_117821.1 \\
\hline ROS8 & Pseudomonas lactis & 627 & 601 & 99 & NR_156986.1 \\
\hline SC1 & Arthrobacter globiformis & 426 & 254 & 87 & NR_112192.1 \\
\hline SC2 & Arthrobacter globiformis & 676 & 1919 & 97 & NR_026236.1 \\
\hline SC3 & Arthrobacter oxydans & 1260 & 950 & 96 & NR_112192.1 \\
\hline SC6 & Pseudomonas mandelii & 1172 & 1775 & 98 & NR_114216.1 \\
\hline SC8 & Pseudomonas mandelii & 1218 & 1459 & 96 & NR_114216.1 \\
\hline SC10 & Pseudomonas mandelii & 1177 & 1655 & 96 & NR_114216.1 \\
\hline SC11 & Pseudomonas prosekii & 580 & 883 & 99 & NR_132724.1 \\
\hline SC12 & Pseudomonas meridiana & 610 & 944 & 99 & NR_025587.1 \\
\hline SC13 & Pseudomonas prosekii & 653 & 1016 & 99 & NR_132724.1 \\
\hline SC14 & Pseudomonas mandelii & 1202 & 2021 & 99 & NR_114216.1 \\
\hline SC15 & Pseudomonas meridiana & 1713 & 1858 & 95 & NR_025587.1 \\
\hline SC17 & Pseudomonas meridiana & 1168 & 1777 & 96 & NR_025587.1 \\
\hline
\end{tabular}


isolated from Spike Cape, Scott Coast, Southern Victoria Land. Regarding Paenibacillus sp., only one strain has been isolated from soil sample originated from Cape Royds, Ross Island that showed proteolytic activity. This bacilli class strain has been detected in a various type of environment including soil, water and plant. Several novel Paenibacillus sp. have been isolated from Antarctic samples such as Paenibacillus antarcticus (Montes et al., 2006) and Paenibacillus wynnii (RodríguezDíaz et al., 2005). Besides, several researchers have reported proteolytic activity of this species previously (Li et al., 2013).

Out of 35 colonies, 10 colonies that showed clear halo zone formation within 24 hours were further analyzed by enzymatic assay. Azo-casein enzymatic assay was performed in order to quantify the proteolytic activity of these bacteria. Azo is a synthetic dye that attaches with the casein molecule and can be measured through absorbance 340 to 440 $\mathrm{nm}$. When this substrate and the bacteria culture was incubated together, protease broke down the Azocasein and thus release the dye into reaction supernatant. Thus, higher absorbance reading implies higher proteolytic activity. This technique was an adaptation of the previous studies (MartínezRosales \& Castro-Sowinski, 2011). Results for the enzymatic assay was illustrated in the graph (Figure 2). From the graph, we can conclude that sample SC8 showed the highest protease activity with reading $0.2012 \pm 0.003$, followed by sample $\operatorname{ROS} 8(0.1953 \pm 0.002)$ and sample SC11 $(0.1843 \pm$ 0.002). Only SC8 showed statistically significant difference with $\mathrm{p}$-value less than 0.05 . It showed higher proteolytic activity compared to $P$. aeruginosa at $20^{\circ} \mathrm{C}$.

In nature, protease plays an important role as a tool for degradation of sedimentary nitrogenous compounds. These compounds were abundantly precipitated in sediments providing nitrogen sources for the microorganisms including in Antarctic regions (Dall'Osto et al., 2017; Vero et al., 2019). Evolution of the enzyme sequence and structure enable it to work at lower temperature. Some of the findings displayed that amino acid composition contributes to the flexibility of the enzyme structure and unique loop formation providing more accessible active site (Latip et al., 201; Hashim et al., 2018).

In industrial enzymes, the protease is one of the components used to tenderize the meat, but commercial tenderizer enzyme cannot work at a lower temperature (Naveena et al., 2004; Gokoglu et al., 2017). This cold active protease has the potential to be applied in the poultry industries. This is because, after processing the meat, they will be stored in the freezer for long-term storage or for export purposes. In order to take advantage while storing, this enzyme can be applied to the meat. Therefore, once the customer buys it, it will be ready for cooking. With this initiative, it will be time and energy saving. Besides, the end user also can apply this cold active protease when they want to cook the meat, after taking out of cold storage. This coldactive protease also has been studied on their potential for detergent industries (Park et al., 2018).

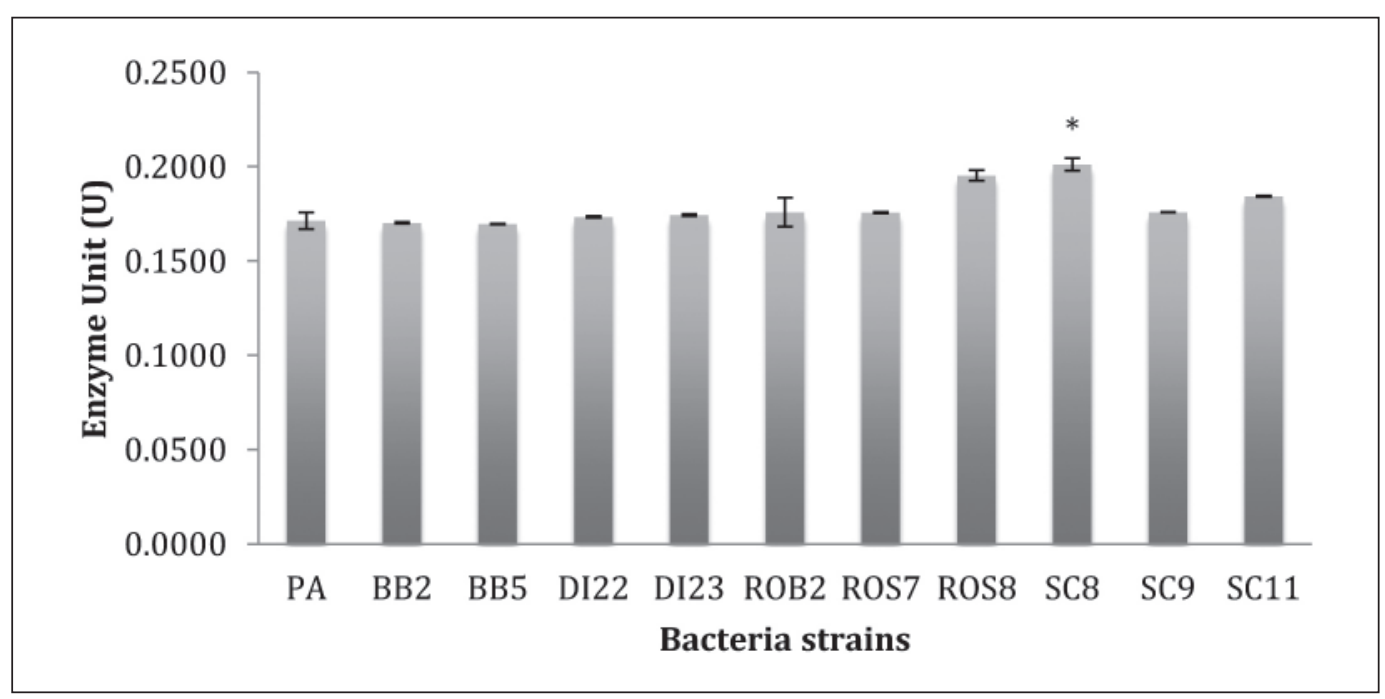

Fig. 2. Protease activity of ten selected bacteria strains after 24 hours incubation period at $20^{\circ} \mathrm{C}$ and 200 rpm. $P$. aeruginosa (PA) was used as positive control. Results were expressed as mean $\pm \mathrm{SEM} .{ }^{*} p<0.05$. 


\section{CONCLUSION}

Enzymes have been widely accepted as substitute to the chemical catalysts. This biocatalyst has played a major role not only at industries level but also in our daily life. Overall, we have successfully discovered cold active protease activity produced by psychrophiles isolated from Antarctic region. In future, purification and characterization of this enzyme is essential in order to identify the optimum conditions for enzyme activity. Once the optimum conditions meet the market demand, production of this enzyme can be scaled up for commercialization purpose.

\section{ACKNOWLEDGMENTS}

This work was supported by research grants from Yayasan Penyelidikan Antartika Sultan Mizan (YPASM) 2015 and RIGS 16-332-0496. The field survey and sampling were made possible with funding to J. Smykla from the Polish National Science Center within grant no. NN305376438 and through logistic support supplied the US Antarctic Program NSF.

\section{REFERENCES}

Barroca, M., Santos, G., Gerday, C. \& Collins, T. 2017. Biotechnological Aspects of Cold-Active Enzymes. In Psychrophiles: From Biodiversity to Biotechnology, Springer, Cham. 461-475.

Brown, M.R.W. \& Foster, J.S. 1970. A simple diagnostic milk medium for Pseudomonas aeruginosa. Journal of Clinical Pathology, 23(2): 172-177.

Chen, Y.L., Lee, C.C., Lin, Y.L., Yin, K.M., Ho, C.L. \& Liu, T. 2015. Obtaining long $16 \mathrm{~S}$ rDNA sequences using multiple primers and its application on dioxin-containing samples. BioMed Central Bioinformatics, 16(18): S13.

Dall'Osto, M., Ovadnevaite, J., Paglione, M., Beddows, D.C., Ceburnis, D., Cree, C., Cortés, P., Zamanillo, M., Nunes, S.O., Pérez, G.L. \& Ortega-Retuerta, E. 2017. Antarctic sea ice region as a source of biogenic organic nitrogen in aerosols. Scientific Reports, 7(1): 1-10.

De Maayer, P., Anderson, D., Cary, C. \& Cowan, D.A. 2014. Some like it cold: understanding the survival strategies of psychrophiles. European Molecular Biology Organization Reports, 15(5): 508-517.
Elleuche, S., Schröder, C., Sahm, K. \& Antranikian, G. 2014. Extremozymes - biocatalysts with unique properties from extremophilic microorganisms. Current Opinion in Biotechnology, 29: 116-123.

Gokoglu, N., Yerlikaya, P., Ucak, I. \& Yatmaz, H.A. 2017. Effect of bromelain and papain enzymes addition on physicochemical and textural properties of squid (Loligo vulgaris). Journal of Food Measurement and Characterization, 11(1): 347-353.

Harer, S.L., Bhatia, M.S. \& Bhatia, N.M. 2018. Isolation, purification and partial characterization of thermostable serine alkaline protease from a newly isolated Bacillus thuringinsis-SH-II-1A. African Journal of Biotechnology, 17(7): 178-188.

Hashim, N.H.F., Mahadi, N.M., Illias, R.M., Feroz, S.R., Bakar, F.D.A. \& Murad, A.M.A. 2018. Biochemical and structural characterization of a novel cold-active esterase-like protein from the psychrophilic yeast Glaciozyma antarctica. Extremophiles, 22(4): 607-616.

Kim, E.H., Cho, K.H., Lee, Y.M., Yim, J.H., Lee, H.K., Cho, J.C. \& Hong, S.G. 2010. Diversity of cold-active protease-producing bacteria from arctic terrestrial and marine environments revealed by enrichment culture. The Journal of Microbiology, 48(4): 426-432.

Latip, M.A.A., Hamid, A.A.A. \& Nordin, N.F.H. 2019. Microbial hydrolytic enzymes: In silico studies between polar and tropical regions. Polar Science, 20: 9-18.

Li, Y., Pan, Y., She, Q. \& Chen, L. 2013. A novel carboxyl-terminal protease derived from Paenibacillus lautus CHN26 exhibiting high activities at multiple sites of substrates. BioMed Central Biotechnology, 13(1): 89.

Martínez-Rosales, C. \& Castro-Sowinski, S. 2011. Antarctic bacterial isolates that produce coldactive extracellular proteases at low temperature but are active and stable at high temperature. Polar Research, 30(1): 7123.

Montes, M.J., Mercadé, E., Bozal, N. \& Guinea, J. 2004. Paenibacillus antarcticus sp. nov., a novel psychrotolerant organism from the Antarctic environment. International Journal of Systematic and Evolutionary Microbiology, 54(5): 1521-1526.

Naveena, B.M., Mendiratta, S.K. \& Anjaneyulu, A.S.R. 2004. Tenderization of buffalo meat using plant proteases from Cucumis trigonus Roxb (Kachri) and Zingiber officinale roscoe (Ginger rhizome). Meat Science, 68(3): 363-369. 
Reddy, G.S., Matsumoto, G.I., Schumann, P., Stackebrandt, E. \& Shivaji, S. 2004. Psychrophilic pseudomonads from Antarctica: Pseudomonas antarctica sp. nov., Pseudomonas meridiana sp. nov. and Pseudomonas proteolytica sp. nov. International Journal of Systematic and Evolutionary Microbiology, 54(3): 713-719.

Rodríguez-Díaz, M., Lebbe, L., Rodelas, B., Heyrman, J., De Vos, P. \& Logan, N.A. 2005. Paenibacillus wynnii sp. nov., a novel species harbouring the nifH gene, isolated from Alexander Island, Antarctica. International Journal of Systematic and Evolutionary Microbiology, 55(5): 2093-2099.

Park, H.J., Han, S.J., Yim, J.H. \& Kim, D. 2018. Characterization of an Antarctic alkaline protease, a cold-active enzyme for laundry detergents. The Microbiological Society of Korea, 54(1): 60-68.

Pindi, P.K., Manorama, R., Begum, Z. \& Shivaji, S. 2010. Arthrobacter antarcticus sp. nov., isolated from an Antarctic marine sediment. International Journal of Systematic and Evolutionary Microbiology, 60(10): 2263-2266.
Siddiqui, K.S. \& Cavicchioli, R. 2006. Coldadapted enzymes. Annual Review of Biochemistry, 75: 403-433.

Smykla, J., Drewnik, M., Szarek-Gwiazda, E., Hii, S.Y., Knap, W. \& Emslie, S.D. 2015. Variation in the characteristics and development of soils at Edmonson Point due to abiotic and biotic factors, northern Victoria Land, Antarctica. Catena, 132: 56-67.

Tang, Y., Wu, P., Jiang, S., Selvaraj, J.N., Yang, S. \& Zhang, G. 2019. A new cold-active and alkaline pectate lyase from Antarctic bacterium with high catalytic efficiency. Applied Microbiology and Biotechnology, 1-11.

Vero, S., Garmendia, G., Martínez-Silveira, A., Cavello, I. \& Wisniewski, M. 2019. Yeast Activities Involved in Carbon and Nitrogen Cycles in Antarctica. In The Ecological Role of Micro-organisms in the Antarctic Environment, Springer, Cham. 45-64. 